\title{
European integration: a meeting ground for history and political science? A historian responds to Andrew Moravesik
}

\author{
Melissa PINE
}

European integration has been a fertile subject for research by both historians and political scientists. ${ }^{1}$ These different disciplines bring different tools to studying the past, focus on different aspects and find and proclaim different 'truths' - or perhaps the impossibility of so doing - as a result. Yet how should we frame and practice our research? Social scientists have been at the forefront of answering this question explicitly and of focusing on methods and practices drawn from the 'hard' sciences. As John Lewis Gaddis has recently noted, historians have been less concerned - indeed have positively recoiled from - making the methods that underlie writing history more apparent. ${ }^{2}$ In the study of European integration, partly as a result of this methodological disparity and the discursive gulf that results from it, there remain two distinct groups of scholars, researching the same people and events and often using the same resources, but producing widely (and sometimes wildly) differing scholarship.

This article, written by an historian, focuses on the work of Andrew Moravcsik, a prominent and often controversial political scientist. ${ }^{3}$ It analyses the development of his theory of European integration through five of his publications. It then moves on to comment on his method of working and use of sources. The article concludes that Moravcsik's very practice as a social scientist who begins with forming theory and then moves to test it empirically causes problems for historians who seek to engage with his work. His source use is also problematic from the perspective of the historian. However, the challenging and provocative nature of Moravcsik's work ultimately forces us to be better historians.

\section{Evolution of a theory}

Over the course of his professional career, Moravcsik has produced a large corpus of work over a wide range of topics. ${ }^{4}$ This section presents an overview of five articles in which he concentrates on European integration. This is not intended to

1. Thanks to Anne Deighton, Anand Menon, Helen Parr and anonymous peer reviewers for their comments on this article.

2. J.L. GADDIS, The Landscape of History: How Historians Map the Past, Oxford University Press, Oxford, 2002, p xi.

3. The author is an historian, recovering from two years of formal training in political science.

4. For a full list of publications see Moravcsik's webpage at http://www.princeton.edu/ amoravcs/ index.html. 
be a comprehensive review article: space does not permit a full analysis of Moravcsik's prolific output. Moreover, the two works perhaps best known to historians have not been included: both his 1998 book 'The Choice for Europe, Social Purpose and State Power from Messina to Maastricht' and his 2000 two-part article, 'De Gaulle between Grain and Grandeur: The Economic Origins of French EC Policy, 1958-1970' have already received great scrutiny from historians. ${ }^{5}$ Instead, articles less well known in the historical community have been selected, from across the duration of Moravcsik's career so far. For each, the main theoretic claim and assumptions are stated, and these claims and assumptions are explored from an historical perspective, drawing on some of the comments and criticism that Moravcsik's work has engendered.

\section{Negotiating the Single European Act: National Interests and Conventional Statecraft in the European Community ${ }^{6}$}

Moravcsik first put forward a theory of European integration, then labelled 'intergovernmental institutionalism', in 1991. He begins from a 'modified structural realist' perspective (p.21), starting with the assumptions that states (or rather governments) are rational actors and are the key players in integration, that bargains among them represent lowest common denominator decision-making, and that states will act to protect their sovereignty and national interest, agreeing to integrate only when they do not have a better stand-alone option (pp.25-27). Further, 'modified structural realism' is amended to take account of the fact that states are not unitary actors (p.27). Moravcsik concludes that 'the primary source of integration lies in the states themselves and the relative power each brings to Brussels'. He acknowledges that his explanation is incomplete, and concedes a role to supranational institutions in 'cementing existing interstate bargains' once they are made, but nevertheless contends that state actors play the central role in furthering integration, and that it is driven primarily by (economic) policy convergence (p.56 and p.21). The negotiation of the Single European Act, and in particular the 1992 initiative, is explored to test this theory.

5. A. MORAVCSIK, The Choice for Europe: Social Purpose and State Power from Messina to Maastricht, Cornell University Press, New York, 1998 and De Gaulle between Grain and Grandeur: The Economic Origins of French EC Policy, 1958-1970, in: Journal of Cold War Studies, 1 and 3(2000). For comment, see H. WALLACE, J. CAPORASO, F. SCHARPF, Review Section Symposium: The Choice for Europe: Social Purpose and State Power from Messina to Maastricht, in: Journal of European Public Policy, 1(March 1999); R.H. LIESHOUT et al, The Choice for Europe: Soft Sources, Weak Evidence?, in: Journal of Cold War Studies, 4(2004); S. HOFFMAN, Comment on Moravcsik; J. KEELER, A response to Andrew Moravcsik; A.S. MILWARD, A Comment on the Article by Andrew Moravcsik; J. GILLINGHAM, A Test Case of Moravcsik's 'Liberal Intergovernmentalist' approach to European integration; J. VANKE, Reconstructing de Gaulle; M. TRACHTENBERG, De Gaulle, Moravcsik and Europe, all in: Journal of Cold War Studies, 3(2000).

6. A. MORAVCSIK, Negotiating the Single European Act: National Interests and Conventional Statecraft in the European Community, in: International Organisation, 1(1991), pp.19-56. 
Looked at in itself, 'intergovernmental institutionalism' is a neat and compelling theory. However, as Anthony Forster has shown, many of the assumptions that support the theory, in three distinct elements - the formation of preferences, the vision of governments as purposeful actors, and the process of bargaining itself - do not stand up under empirical analysis. ${ }^{7}$ These will be discussed in more detail with reference to the next article, below. More fundamentally, the primary objection to Moravcsik's work in 'Negotiating the Single European Act' is surely the choice of subject matter for empirical testing. Using an intergovernmental conference to prove that governments play the key role in integration suggests a slanted choice of evidence to support a particular point of view. Heads of state and government are by definition the primary actors in an intergovernmental conference: studying an IGC to prove that heads of state and government are key players is teleological. Fritz Scharpf's comments on 'The Choice for Europe' apply equally here:

'Since only intergovernmental negotiations are being considered, why shouldn't the preferences of national governments have shaped the outcomes? Since all case studies have issues of economic integration as their focus, why shouldn't economic concerns have shaped the negotiating positions of governments? And since only decisions requiring unanimous agreement are being analysed, why shouldn't the outcomes be affected by the relative bargaining powers of the governments involved?'.8

Ironically, Moravcsik criticises others for this failing, pointing out in 'Preferences and Power' that neo-functionalist writers 'limited their definition of integration almost exclusively to institutional characteristics of the EC' (p.479).

Other claims in this article demand further analysis. For example, Moravcsik argues that individuals with a role in the supranational institutions did not play an important part in the IGC (pp.46-47). He notes later, however, that Jacques Delors, president of the European Commission, was one of four people who made 'key decisions' on European policy in France (p.50). Surely Delors did not have to have a formal role in the IGC deliberations, therefore, to have influence over their outcome. His influence on François Mitterrand - whose conversion to free market liberalism was so important to reaching agreement on the Single European Act (SEA) - is surely worthy of further discussion. In a similar vein, while Moravcsik's efforts to 'open up the state' instead of treating each state as a unitary actor are important, the state is the only actor so treated, and it is only 'disaggregated' in the case of preference formation. If IGCs are the focus, it would surely be instructive to look in more detail at exactly how heads of state or government prepare for them: who actually draws up positions, for example? In the author's work, statements made at head of government level often replicate, word for word, briefing notes

7. A. FORSTER, Britain and the Negotiation of the Maastricht Treaty: A Critique of Liberal Intergovernmentalism, in: Journal of Common Market Studies, 3(1998), pp.347-368 and especially pp.357-365.

8. F. SCHARPF, Selecting cases and testing hypotheses, in: H. WALLACE, J. CAPORASO, F. SCHARPF, Review Section Symposium ..., op.cit., p.165. 
drawn up by, for example, permanent representatives to the EC. ${ }^{9}$ Where does responsibility for a 'national position' lie? Can the 'position' of Margaret Thatcher in the SEA be untangled from the process that produced it? Must it be assumed that national officials, whether based in state capitals or in Brussels, share the same 'rational' and 'national' interest as the governments they serve? In other words, can the archival record shed light on how national preferences are formed? Ministers and officials, together with other national actors like trades unionists, business leaders or media commentators leave behind copious evidence of efforts at shaping negotiating policy, but it is not explored here. Continued deconstruction of Moravcsik's assumptions compels other questions. Can the dividing line between 'the state' and 'Europe' be clearly identified when many of those involved in the preparation of 'national' preferences are based full time in European institutions like COREPER or meet regularly in European ministerial councils? Would the convergence of national policies have had any significance if there had been no Delors to capitalise upon it? Would it have been so marked if the states concerned had not been bound together in the existing structure of the EC? At the most basic level, does membership of the EC/EU change the nature of 'nation states' so that models drawn from theories of international relations or comparative government do not, in fact, make a best fit? ${ }^{10}$ An echo of each of these questions is raised by each of the articles assessed below.

\section{Preferences and Power in the European Community: A Liberal Intergovernmentalist Approach ${ }^{11}$}

In this 1993 article, Moravcsik expands, elaborates and modifies his original 'intergovernmental institutionalism' and re-labels it 'liberal intergovernmentalism' (LI). He begins with a controversial and provocative claim, that from the Treaty of Rome to the Maastricht Treaty, 'the EC has developed through a series of celebrated intergovernmental bargains, each of which set the agenda for an intervening period of consolidation' (p.473). He sums up his claims in the introduction:

'The EC can be analysed as a successful intergovernmental regime designed to manage economic interdependence through negotiated policy coordination. Refinements and extensions of existing theories of foreign economic policy, intergovernmental negotiation and international regimes, provide a plausible and generalisable explanation of its evolution. Such theories rest on the assumption that state behaviour

9. For example, compare briefing note in 'Report of visit to Soames and attached paper, Hancock to Maitland, 10 February 1969' with 'Record of a Meeting between the Prime Minister and the Federal German Chancellor at the Federal Chancellery, Bonn, at 4pm on Wednesday, February 12, 1969', both in: The National Archive, Kew London PREM/13/2628.

10. For discussion of these questions, see W. SANDHOLTZ, Membership Matters: Limits of the Functional Approach to European Institutions, in: Journal of Common Market Studies, 3(1996).

11. A. MORAVCSIK, Preferences and Power in the European Community: A Liberal Intergovernmentalist Approach, in: Journal of Common Market Studies, 4(1993), pp.473-524. 
reflects the rational actions of governments constrained at home by domestic societal pressures and abroad by their strategic environment. An understanding of the preferences and power of its Member States is a logical starting point for analysis. Although the EC is a unique institution, it does not require a sui generis theory' (p.474).

According to this theory, integration occurs in three stages. First, governments formulate preferences - aggregating them on the basis of preferences expressed by domestic groups, in the context of international constraints. Next, they come to agreement in international negotiations, where relative bargaining power is determined by differential preference intensity. Finally, they pool sovereignty in institutions for the fulfilment of the agreements just made in order to minimise transaction costs and to control domestic agendas. 'Preferences and Power' thus augments the theory set out in 'Negotiating the Single European Act', in particular delineating more detailed models of preference formation, of state power in EC negotiations, and of the circumstances under which states pool sovereignty in institutions.

The above-stated fundamental objection to Moravcsik's practice - focusing on IGCs in order to test a theory of the primacy of the role of states in European integration - must be restated here, and for each of the works in which he presents a theory of European integration. Indeed, its restatement of this claim ensured that 'Preferences and Power' attracted a great deal of comment. Identifying, but then ignoring, 'federalist' and 'national security' motivations for governments to pursue integration in favour of concentrating on economic interdependence further constrains the focus of empirical research (pp.484-485). Two responses are noted here. Daniel Wincott argues that 'liberal intergovernmentalism' is not a theory at all, and that Moravcsik's work is illegitimately biased. ${ }^{12}$ He confronts Moravcsik's claim that integration proceeds by grand bargains, which are consolidated in the periods between treaty-making negotiations. Thus he explores the 'daily grind' of European integration, widening the focus from intergovernmental negotiations themselves to conclude specifically that 'many of the 'innovations' of the Single European Act were already the day-to-day practice of the Community' (p.603). Moravcsik replied with a further claim that such day-to-day practice, as in the development of EC environmental policy, was initiated in the European Council or the Council of ministers rather than the supranational institutions, so that it reinforces his theory rather than undermining it. However, no empirical evidence is given. ${ }^{13}$

Wincott also suggests that Moravcsik's focus on the economic field causes him to ignore 'the innovations which were genuinely introduced by the SEA' and that the role of supranational institutions demands further research (p.606 and p.608) surely, removing the word 'institutionalism' from the name of his theory aptly

12. D. WINCOTT, Institutional Interaction and European Integration: Towards an Everyday Critique of Liberal Intergovernmentalism, in: Journal of Common Market Studies, 4(1995), pp.597-609.

13. A. MORAVCSIK, Liberal Intergovernmentalism and Integration: A Rejoinder, in: Journal of Common Market Studies, 4(1995), p.618 
indicates Moravcsik's disregard for the significance that supranational institutions, like the European Commission or Parliament, might play in the organisation or furthering of integration. His response to Wincott's challenge focuses on the initial decision of states to delegate or pool sovereignty to institutions and a theoretical, principal-agent derived model of the control that states exercise over institutions once they are created. ${ }^{14}$ It is therefore not particularly enlightening regarding how integration might proceed (or, alternatively, not proceed) in between treaty-revising conferences.

Forster, on the other hand, continues his more in-depth and empirically-based assessment of each of Moravcsik's assumptions. ${ }^{15}$ Taking just two examples, Forster suggests first that, at Maastricht, national preferences emanated from governments themselves, rather than from societal groups. In the Maastricht negotiations the British Conservative government was focused not on aggregating preferences expressed by national groups, but on maintaining party and cabinet cohesion (p.358). Second, the example of social policy demonstrates that the outcome of negotiations is not always based on the "need to compromise with the least forthcoming government' (p.361). Moravcsik's assertion that governments are powerful through not wanting particular policies (having 'asymmetries in the relative intensity of national preferences', p.499) is intuitively unsatisfactory; Forster demonstrates that it is empirically baseless.

Two broad comments may be made. First, Moravcsik is forced to consider multiple alternative variables in explaining the way in which 'the EC has developed', as he put it in his abstract. Taking account of these variables makes his account of European integration fuller and more persuasive, but it undermines the elegance and parsimony of his original statement that 'the EC has developed through a series of celebrated intergovernmental bargains, each of which set the agenda for an intervening period of consolidation'. Second, several of the key assumptions on which LI rests seem, on the basis of empirical research, to be invalid or otherwise flawed.

\section{Explaining the Treaty of Amsterdam: Interests, Influence, Institutions ${ }^{16}$}

In this 1999 article, Moravcsik works with Kalypso Nicolaides: their research questions are shaped by LI theory. They seek to explain not European integration in its entirety, but rather, 'the process and outcome of the negotiation of the Treaty of Amsterdam'. They ask what explains 'the national preferences of the major governments'; given these, 'what explains bargaining outcomes among them'; and finally, given these outcomes, "what explains the choice of international institution

14. Ibid., pp.621-625.

15. A. FORSTER, Britain and the Negotiation ..., op.cit.

16. A. MORAVCSIK, K. NICOLAIDES, Explaining the Treaty of Amsterdam: Interests, Influence, Institutions, in: Journal of Common Market Studies, 1(1999), pp.59-85. For another view by the same authors, see Keynote Article: Federal Ideals and Constitutional Realities in the Amsterdam Treaty, in: Journal of Common Market Studies, Annual Review, 1998. 
to implement them'. They conclude that '[i]ssue-specific interdependence explains national preferences. Interstate bargaining based on asymmetrical interdependence explains the outcomes of substantive negotiations. The need for credible commitments explains institutional choices to pool and delegate sovereignty'. All other factors, like ideology or supranational entrepreneurship, are secondary (p.59). In this way, the Amsterdam Treaty is 'like the previous 'grand bargains' in EU history' (p.60).

This article omits the grand theoretical claims seen in the two previously discussed. Moravcsik and Nicolaides' modelling in researching the Amsterdam Treaty is much more nuanced, particular and open to interpretation even than the stark statements in the abstract, quoted above. The results are therefore much less constrained by LI theory than might be expected from the earlier work. The authors illustrate multiple causal factors in explaining the process and outcome of the Amsterdam negotiation, and acknowledge several possible exceptions to the explanation set out in the abstract. Fitting the abstract and the main body of research together, therefore, is challenging. Several examples follow.

First, in the arena of preference formation, since the authors concede that 'learning' during negotiations is possible (impossible under Moravcsik's earlier assumption of perfect information from the outset), the previous analytical and, by implication, temporal distinction between preference formation, on one hand, and bargaining, on the other, must be thrown out. Preference formation is downgraded to 'a rational ranking of concerns about issue-specific interdependence' (p.62). Moreover, the significance of both the very existence of the EU, and also the process of intergovernmental negotiation, for national preference formation is clear. In Moravcsik's earlier work, as has been seen, governments merely aggregated group preferences in the domestic setting, with an acknowledgement of the constraints imposed by the international context but nothing more. Here, not only is it acknowledged that some national positions were dependent on the outcome of other negotiations, but the authors also note that there was a perception (at least) that the negotiations themselves could have a significant impact on the domestic politics of the member states: the Council's hesitation to publicise its own positions for fear of aiding the British Conservative party is a case in point (p.67). As a result, the analysis seems much more persuasive, but it is also much more complex, and surely further from 'parsimonious theory' than Moravcsik's earlier work.

Second, in a throwaway comment, Moravcsik and Nicolaides overturn another of Moravcsik's earlier claims: they contrast the negligible role that supranational actors played in Amsterdam with the 'exceptional opportunity' taken by such actors 'to mobilise [...] potentially powerful transnational interests' during the negotiation of the SEA - a position rejected by Moravcsik in 'Negotiating the Single European Act', as has been seen (p.72).

Third, several different factors creep into the explanation of the result of bargaining: while differential preference intensity is still the primary factor, the authors mention states being willing to make concessions with 'small, if still 
extant, costs' in the 'Christmas tree effect'; the acceptance of undesirable integration because of the desire to avoid 'crisis' or 'to demonstrate a co-operative attitude', even in the case of large, powerful states like Britain; the use of both new and old flexibility options such as protocols and constructive abstention to facilitate agreement (pp.73-75). Similarly, in explaining the pooling of sovereignty in institutions, exceptions to the rule of seeking 'credible commitment' to the bargains just made are acknowledged in the cases of Italian and British positions on the extension of Qualified Majority Voting in the Council; or in deferring a potential agreement on changing representation in the Council and Commission to some future negotiation. There are other oddities. Moravcsik and Nicolaides comment on how the governments 'seemed relatively unconstrained by the previously existing institutional structure', as though that flexibility were something new in European integration. They casually mention 'the potential for uncontrolled spillover to take place', a concept hitherto rejected by Moravcsik. These and other factors are acknowledged 'to increase unpredictability', undermining the hopes of liberal intergovernmentalist theory to have a predictive value. (pp.76-81). The work of other scholars, such as Simon Hug and Thomas König on the significance of ratification hurdles to both preference formation and negotiations, only increases complexity and the consequent difficulty of prediction. ${ }^{17}$

Despite these exceptions and caveats, in their conclusion Moravcsik and Nicolaides restate liberal intergovernmentalism and argue that '[a]lternative explanations [...] provide superior explanations for only a few aspects of the Amsterdam Treaty' (p.82). They conclude that the 'primary lesson of Amsterdam for bargaining theory is [...] that no amount of institutional facilitation or political entrepreneurship, supranational or otherwise, can overcome underlying divergence or ambivalence of national interest' (p.83). Once again, therefore, given that the focus of research is an intergovernmental conference, the authors are stating the obvious. Thus although they finish with a call for more research - both empirical testing and theoretical refinement - the clear necessity of handling multiple variables and of dealing with the role of contingency undermines the both the coherence, and, surely, the elegance of the original theoretical statement - even in assessing one set of treaty-amending negotiations, let alone theorising European integration in toto. In a footnote, Moravcsik and Nicolaides not only acknowledge that liberal intergovernmentalism 'does not constitute a general theory of European integration', they assert that '[n]either one of us believes such a theory exists' (fn p.60). This inconspicuous disavowal jars with Moravcsik's earlier statements, for example that 'the primary source of integration lies in the states' or that 'the EC has developed through a series of celebrated intergovernmental bargains', quoted above.

17. S. HUG, Th. KÖNIG, In View of Ratification: Governmental Preferences and Domestic Constraints at the Amsterdam Intergovernmental Conference, in: International Organisation, 2(2002), pp.447-476. 


\section{A New Statecraft? Supranational Entrepreneurs and International Co-operation ${ }^{18}$}

In the same year, Moravcsik moved his attention from states to the supranational institutions of the EU, responding to the claims of some neo-functionalist writers by specifically focusing on the informal power of supranational actors in intergovernmental negotiations (rather than formal powers in the day-to-day working of the EU). He rejects the neo-functionalist assessment that such informal powers are significant, instead 'privileging the role of national governments and domestic politics', testing this theory against 'all five major treaty-amending decisions in the [then] forty years of EC history': the Treaty of Rome, the Common Agricultural Policy, the European Monetary System, the SEA and the Maastricht Treaty on European Union (p.269). He concludes that in most cases, supranational intervention was 'late, redundant, futile and sometimes even counterproductive' (p.270). The empirical research for this article is drawn from Moravcsik's book, 'The Choice for Europe'.

Moravcsik's analysis is thus much more tightly bounded in 'A New Statecraft' than in the first two articles examined here: there is no attempt to extrapolate the findings of the lack of power for supranational actors in interstate negotiations to European integration more generally, for example. Nevertheless, he maintains his assumption that IGCs tend to result in significant new integration, rather than codifying existing practice, as discussed above: it still requires closer empirical examination. Further, responding to the neo-functionalist position, as Moravcsik sees it, does not necessarily mean confining attention to IGCs: do supranational actors have influence in the day-to-day business of European integration, and if so, how does that influence shape the options before governments in IGCs? More specifically, Oran Young takes issues with Moravcsik's analysis within an explicitly social scientific framework. Young draws attention to what he sees as 'significant ambiguities' in the article. He suggests that Moravcsik has underestimated or over-simplified the variety of types of leadership that supranational actors can provide, and that the opportunities to exercise such leadership are broader than Moravcsik allows.

This misperception draws on another: Young argues that international bargaining is not as rational or efficient as is implied by Moravcsik: ' $N$-person interactions are far more complex and far less deterministic than Moravcsik's vision seems to apply', so that there are many more openings in which supranational actors can exercise leadership than the tightly defined occasions listed in 'A New Statecraft'. Young admits that his own work on other international bargaining may not be applicable to the EU. ${ }^{19}$ However, part of Moravcsik's argument is that, although the EU itself is sui generis, the theoretical tools from

18. A. MORAVCSIK, A New Statecraft? Supranational Entrepreneurs and International Co-operation, in: International Organisation, 2(1999), pp.267-306.

19. O. YOUNG, Comment on Moravcsik, "A New Statecraft? Supranational Entrepreneurs and International Co-operation”, in: International Organisation, 4(1999), pp.805-809. 
other aspects of political science may be applied to it. Moravcsik replies to Young's criticism with a claim that the latter has not confronted his 'detailed theoretical and empirical analysis'.$^{20}$ Nevertheless, Young's conclusion that Moravcsik's analysis 'raises more questions than it answers' is a compelling one. ${ }^{21}$

Some of those questions may best be expressed counterfactually. Taking just one example, Moravcsik dramatically downplays the role one of the 'founding fathers' of Europe, Jean Monnet in explaining European integration. By beginning with the Treaty of Rome, however, Moravcsik misses an opportunity to assess Monnet's role at the foundation of the first European Community, the European Coal and Steel Community (ECSC), in the Treaty of Paris. Would there have been a Treaty of Paris - which Moravcsik ignores throughout his scholarship - without Monnet? What was his input to the creation of the European Coal and Steel Community (ECSC), and to what extent did that input transfer into the creation of the EEC and EURATOM? One might imagine that writing the proposals known as the 'Schuman Plan' and resulting - after intergovernmental negotiation - in the ECSC constitutes 'influence'. Moravcsik mentions only Monnet's 'advocacy of the Schuman Plan' and his advocacy and organisational skills toward the Treaty of Rome, but does not address the creation of the ECSC itself (p.286). The same query must apply to this article, therefore, as to 'The Choice for Europe': why start with the Treaty of Rome and not the Treaty of Paris, alliteration in subtitles not withstanding? Moravcsik insists that supranational actors work within constraints determined by nation state actors, but does not acknowledge that nation state actors work within a context originally framed and proposed by a supranational actor in the Treaty of Paris.

\section{What Can We Learn from the Collapse of the European Constitutional Project? ${ }^{22}$}

In the last substantive article addressed here, Moravcsik examines the creation of the European Constitution. He addresses three assumptions about participatory politics that he believes underlay the decision to hold a constitutional convention: that increasing the opportunity for participation generates increased public participation, that increased participation creates more informed deliberation and decision making, and that popular deliberation creates institutional trust, shared identity and political legitimacy (pp.222-234). He presents evidence (empirical, anecdotal, intuitive and often unreferenced) that each of these assumptions is flawed and that, as a result, the constitutional experiment was doomed to failure. Further, he states that understanding this failure should pre-empt any further

20. A. MORAVCSIK, Theory and Method in the Study of International Negotiation: a Rejoinder to Oran Young, in: International Organisation, 4(1999), pp.811-814.

21. O. YOUNG, Comment on Moravcsik ..., op.cit., p.809.

22. A MORAVCSIK, What can we learn from the Collapse of the European Constitutional Project, in: Forum with F. SCHARPF, M. ZUERN, W. WESSELS, A. MAURER, Politische Vierteljahresschrift, 2(2006), pp219-241. 
attempt to politicize European integration through the use of referenda or alternative constitutions. Finally, 'the failure of the constitutional project in fact demonstrates the Europe's [sic] stability and success' (p.235).

Moravcsik's exploration and denunciation of the assumptions that, as he sees it, underlay the 'constitutional experiment' are interesting and credible, but they are utterly unsubstantiated. He gives no hard evidence for his assertion that the constitutional convention and its output were 'an exercise in public relations' (p.220). In fact, his single use of primary sources (conversations with unidentified European parliamentarians 'on the eve of the convention') identifies a desire for more federalism as their motivation for supporting a new constitution, not a desire to engage with the European populace (p.221 and fn). No effort is made to identify the public or private motivations of other actors in pursuing a European constitution.

Moravcsik's characterisation of the final Constitution as instituting only minor reforms and 'tinkering' with the existing order (p.236) fits neatly with the 'PR exercise' approach: if it did not really change anything, then re-branding Europe in order to engage with its populations is the only plausible explanation for its existence. Holding this 'minor reform' position, however, means that Moravcsik skates over the potentially significant reforms that were part of the Constitution: the replacement of the pillared structure of the EU with a unified structure (Articles I-12-17) does not even bear mention; nor does the incorporation of a mutual defence clause (I-41(7)), or the increased potential for 'enhanced co-operation' among sub-groups of the member states (I-44), or the new option of voluntary secession from the Union (I-60). The creation of a non-rotating presidency (I-22) and a new Foreign minister (I-28) rate only the briefest word, with no suggestion of the possible consequences of the establishment of such high profile positions (p.236). No significance is attributed to the codification of rights in Part II of the Constitution: for scholars at least the promise that 'the arts and sciences shall be free from constraint' and that academic freedom 'shall be respected' (II-73) is of interest. ${ }^{23}$ Surely, therefore, a closer reading of the Constitution, in historical perspective, is necessary in order to assess it. Moravcsik argues that we 'must go further to recognise the EU as it is, rather than as we would wish it to be' (p.237): is it possible that he himself is characterising the EU, or perhaps its constitution, as 'less than it is' for the purposes of his argument? Finally, although this article does not engage directly with Moravcsik's broader theorising on the EU, his applause of the replacement in the Constitution of 'ever closer union' with 'unity in diversity', with its implication of a change away from federalist discourse, draws attention again back to his perception of the central role of the member states in integration (p.237).

Over the course of these five articles then, Moravcsik refined his LI theory considerably - and yet at the same time it remains curiously static. On one hand,

23. The full text of the Constitution is available at: http://eur-lex.europa.eu/ JOHtml.do?uri=OJ:C:2004:310:SOM:EN:HTML. 
particularly in the work with Nicolaides, he takes account of an increasing number of variables in explaining European integration. These additions make the theory's representation of the history of European integration fuller and more persuasive, although they must also undermine its predictive capabilities. On the other hand, Moravcsik holds to his central hypothesis that, as stated in his book, 'European integration resulted from a series of rational choices made by national leaders who consistently pursued economic interests' ${ }^{24}$ This article therefore moves on to examine the methodology that has produced these results.

\section{Method}

In seeking to formulate a 'coherent liberal theory' in his 1997 article 'Taking Preferences Seriously: A Liberal Theory of International Politics', Moravcsik sets out his view of what good social science is ${ }^{25} \mathrm{He}$ formulates 'three core theoretical assumptions' and derives from them 'a coherent liberal theory' which, he argues, 'deserves to be treated as a paradigmatic alternative empirically coequal with and analytically more fundamental than the two dominant theories in contemporary IR scholarship: realism and institutionalism'. He states that 'it is widely accepted that any non-tautological social scientific theory must be grounded in a set of positive assumptions from which arguments, explanations, and predictions can be derived'. His aim is a theory with 'superior parsimony, coherence, empirical accuracy, and multicausal consistency'. In exploring these four criteria, Moravcsik makes some weighty claims. Liberal theory explains 'important phenomena overlooked by alternative theories, including the substantive content of foreign policy, historical change, and the distinctiveness of interstate relations among modern Western states'. By correcting biases inherent to realist and institutional theory, liberal theory 'might well supplant many widely accepted realist and institutionalist, as well as constructivist, explanations of particular phenomena in world politics'. By specifying its assumptions, it can be synthesized 'into a multicausal explanation consistent with tenets of fundamental social theory' (pp.513-517). One of the advantages of reformulating theory in this way, Moravcsik suggests, is to 'compel empirical studies to give serious consideration to hypotheses drawn from it and discouraging omitted variable bias' (p.538). He wishes to 'facilitate empirical research that would move us beyond [...] simplistic assertions about the limited explanatory domain of liberal theory (p.541). In discussing a synthesis of different IR theories, Moravcsik calls for 'analytical priority' for liberalism (p.542). He concedes that its 'analytical priority' does not necessarily mean greater explanatory power, 'which is an empirical matter' (fn p.543) and that new insights into international relations could be gained by 'relaxing' the assumptions made here

24. A. MORAVCSIK, The Choice for Europe ..., op.cit., p.3.

25. A. MORAVCSIK, Taking Preferences Seriously: A Liberal Theory of International Politics, in: International Organisation, 4(1997), pp.513-553. 
(pp.547-548). Nevertheless, liberal theory is 'a logically coherent, theoretically distinct, empirically generalisable social scientific theory - one that follows from explicit assumptions and generates a rich range of related propositions about world politics that reach far beyond cases of cooperation among a minority of liberal states' (p.547).

This view of the purpose of theory and thus the practice of social science permeates Moravcsik's other writing. In 'Preferences and Power', he suggests that neo-functionalism may have failed to endure as a theory because 'it lacked a theoretical core clearly enough specified to provide a sound basis for precise empirical testing and improvement' (p.476). Likewise, in his 1999 article 'Is something rotten in the State of Denmark', he criticises constructivist theorists for failing to begin by creating 'distinctive, testable hypotheses' and then finding methods to 'test such hypotheses against alternative theories or a null hypothesis of random state behaviour' (p.670). ${ }^{26}$ The divergence in practice, and thus in underlying epistemology, between history and theory is encapsulated in this quote. What we do first, as scholars, is different, as is how we conceptualise knowledge. Do we begin with assumptions about how the world works, the conception of a theory or model, and then seek to test 'the real world' against it? Or do we begin with empirical research and seek to elaborate an understanding of the past through the evidence that thus emerges? Moravcsik is explicit in this matter. He states that in

'international political economy, as in other social phenomena, it is widely accepted that prediction and explanation, particularly over time, require theories that elaborate how self-interested actors form coalitions and alliances, domestically and internationally, and how conflicts among them are resolved'.

He further asserts that 'theories must be derived independently of the matter being studied', on the basis of a series of assumptions or 'microfoundations' that must be specified beforehand (p.477). In 'Taking Preferences Seriously', he argues that liberal theory implies then doing difficult empirical research:

'State preferences must be clearly distinguished from strategies and tactics and then must be inferred either by observing consistent patterns of state behaviour or by systematically analysing stable elements internal to state, as revealed in decision-making documents, trustworthy oral histories and memoirs, patterns of coalitional support, and the structure of domestic institutions'.

The theory creation comes first, and the empirical research is organised in the light of the theory (pp.543-544).

Most historians do not work this way, and many explicitly reject this method of working. Even Donald Puchala, who otherwise lauds Moravcsik as a scholar on a par with Ernst Haas, notes that the former 'gathers evidence and tests positions derived from' intergovernmentalist positions, implying a certain degree of selection. ${ }^{27}$ Gaddis states simply that 'what we can learn should always figure more

26. A. MORAVCSIK, Is something rotten in the State of Denmark: Constructivism and European Integration, in: Journal of European Public Policy, 4(1999), pp.669-681. 
prominently in our set of priorities than the purity of methods by which we learn it' - a position that Moravcsik would presumably reject outright. ${ }^{28}$ Moreover, as Wincott indicates, Moravcsik contradicts himself in 'Preferences and Power', arguing that 'detailed empirical knowledge' is required to select assumptions in the first place so that, it would seem, assumption formation and theory building cannot precede empirical research (p.498) ${ }^{29}$ In a further anomaly, Moravcsik states that 'the formation of preferences analytically (though not always temporally) precedes bargaining, which in turn precedes delegation' ${ }^{30}$ While forming theories often requires an 'as if' approach, inverting temporal sequences is surely not the optimum approach when studying history: as Gaddis comments, '[y]ou don't have to be a professional historian to understand that causes must precede consequences'. ${ }^{31}$ At a more basic level, historians call the whole use of formal assumptions into question. Are states 'rational actors' - for the given definition of 'rational'? The study of history makes this assumption difficult if not impossible to hold even without taking Moravcsik's dis-aggregation of the state into effect. The deterministic impact of attempting theory-creation before empirical research is immense: deciding that European integration is driven by interstate bargains, and then researching interstate bargains to test the theory is surely problematic. In a footnote to 'In Defence of the Democratic Deficit', Moravcsik comments that other scholars focus on things that are 'important trends, but atypical of the EU as a whole' (fn p.607): how is such a stance defensible when he himself does not research 'the EU as a whole' ${ }^{32}$ The resulting bias in the selection of sources is clear.

\section{Sources}

The final section of this article assesses sources in Moravcsik's empirical research. It suggests that Moravcsik's method of working requires a choice and use of sources that would be problematic for many historians.

27. D. PUCHALA, Institutionalism, Intergovernmentalism and European Integration, in: Journal of Common Market Studies, 2(1999), pp.317-331.

28. J.L. GADDIS, The Landscape of History ..., op.cit., p.109.

29. WINCOTT, 'Institutional Interaction', p 600. Wincott dissents, arguing that 'theoretical guidance' is necessary in determining 'which details of empirical knowledge are significant.'

30. A. MORAVCSIK, Liberal Intergovernmentalism ..., op.cit., p.613, emphasis added.

31. GADDIS, The Landscape of History, p 106.

32. A. MORAVCSIK, In Defence of the Democratic Deficit, in: Journal of Common Market Studies, 4(2002), pp.603-624 and fn p.607. 


\section{Source choice}

All of the articles discussed here are based heavily on secondary sources. 'Negotiating the Single European Act' adds a few newspaper articles (notably from The Financial Times) and occasional references to interviews. In ninety-seven footnotes (some with multiple references, some containing substantive comments) there are twenty-four references to what could be described as primary sources, many of which are drawn from one edited collection. ${ }^{33}$ In 'Preferences and Power', there are no primary sources referenced. 'Explaining the Amsterdam Treaty' draws on some interviews (on which see below) and published primary sources such as Commission reports and the Amsterdam Treaty itself. 'A New Statecraft' is based on the empirical research in the book, 'The Choice for Europe', and includes solely the memoirs of Jean Monnet as extra primary material. 'What Can We Learn' uses Eurobarometer data and one edition of EU Observer.

Relying on secondary sources is not necessarily a cause for censure, and nor is drawing in later scholarship on empirical research done for a major book. However, particularly in the claims made in 'The Choice for Europe', Moravcsik has set himself up for criticism. He asserts on more than one occasion that hard, primary research is necessary for the empirical testing of theory, and that his own work rests on these foundations. In his book, he devotes several pages to discussing the importance of 'hard primary sources', and the 'rigorous methods typically employed by historians' (pp.80-85). Yet in his article, 'The Origins of Human Rights Regimes', Moravcsik reveals a disinclination for archival or other primary research. He notes that Britain is 'a country for which we have a wealth of reliable archival documents and oral histories' - but then goes on to acknowledge that he had 'restricted himself here to materials found in published sources' ${ }^{34}$ No reason is given: perhaps time constraints can be inferred. More elementally from the historian's perspective is the extent to which Moravcsik's use of primary sources has been called into question. Robert Lieshout, Mathieu Segers and Anna Van der Vleuten make a devastating critique of his historical practice in their review article for The Journal of Cold War Studies, concluding that his 'interpretation does not stand up under scrutiny', that his sources are 'soft' and his evidence 'weak' ${ }^{35}$ It is therefore problematic when empirical research in one work is used as a foundation for later scholarship.

\section{Verifiability}

Lieshout et al were at least able to trace Moravcsik's empirical research through his references. However, in each article discussed here, both general claims and particular facts are left unreferenced: in 'Negotiating the Single European Act', for

33. M. GAZZO (ed.), Towards European Union (two volumes), Agence Europe, Brussels, 1985, mistakenly cited here more than once as Towards European Unity.

34. MORAVCSIK, 'The Origins of Human Rights Regimes', fn p 239.

35. R.H. LIESHOUT et al, The Choice for Europe ..., op.cit., p.116. 
example, Moravcsik states without substantiation that many of the 300 legislative items that made up the Single European Act had previously been proposed by the Commission but ignored by governments, using this 'fact' to illustrate the impotence of the Commission (p.47). In 'What can we learn' Moravcsik states, in an entire section based on unsubstantiated claims, that European legislation accounts for 'only about 20\% of European regulation and legislation' (p.235). His argument in this section - that Europeans are satisfied with the existing 'constitutional settlement' in Europe - is persuasive, but it is not verifiable. Further, interviewees are not consistently identified, making it impossible to try to replicate Moravcsik's research. 'Explaining the Treaty of Amsterdam' cites an 'interview with five Commission officials'. Interviews with Michel Petite and Richard Corbett are mentioned in both this article and Moravcsik and Nicolaides' 'Keynote Article', but in neither is a job title nor full details of the interview given ${ }^{36}$ Elsewhere, Moravcsik refers to "those European parliamentarians with whom I spoke on the eve of the convention'. ${ }^{37}$ If interviewees have spoken on the condition of anonymity (under the 'Chatham House Rule'), the methodological consequences of using their testimony should be addressed. ${ }^{38}$

\section{Self-citation}

A linked issue methodologically is Moravcsik's marked proclivity for citing his own work, which increases notably from 1991 to the present. In the earliest article examined here, 'Negotiating the Single European Act', Moravcsik cites himself just once. 'Preferences and Power' has three self-references in the thirty-three footnotes and there are a further eight in the text. 'Explaining the Amsterdam Treaty' contains a total of eighteen references to the earlier work of Moravcsik or Nicolaides or both. In 'A New Statecraft', fifteen of ninety-four footnotes include self-references, and as has been seen, the whole empirical research is drawn from 'The Choice for Europe'. 'What Can We Learn' has thirteen self-references. Moravcsik may be the authority on LI theory, and may choose to cite his earlier work rather than restating arguments or evidence previously laid out. However, self-citation is clearly risky when both Moravcsik's assumptions and his empirical proofs have been called into question by social scientists and historians alike. On several levels, therefore, Moravcsik's source use is problematic.

36. A. MORAVCSIK, K. NICOLAIDES, Explaining the Treaty of Amsterdam ..., op.cit., fn p.70, and Keynote Article, op.cit.

37. A. MORAVCSIK, What Can We Learn ..., op.cit., fn p.221. This practice is not confined to Moravcsik: see also A. FORSTER, Britain and the Negotiation ..., op.cit.

38. Contrast R. ULLMAN, The Covert French Connection, in: Foreign Policy, 75(1989), pp,3-33. 


\section{Conclusions}

Moravcsik himself noted that 'the world contains more complexity than any single theory can encompass'. ${ }^{39}$ If historians have difficulty with his theories, his assumptions, his methodology and his sources, then why even try to engage with his work - and by extrapolation, with the work of other theorists of European integration? The short answer is that Moravcsik forces a response: his work is so confident and provocative that it is impossible to step away and decline to join battle. Each of the small, substantive questions in this article demands an answer: to what extent did Monnet's role in the creation of the ECSC have an impact in later integration? Did Delors' influence in Paris translate into influence in the negotiation of the Single European Act, and if so, how? Is there an historical pattern in whether IGCs break new ground or consolidate existing practices in European integration? To what extent have government preferences been formed before the start of any given negotiation, how were they formed, and how much has each government known about the preferences of the other member governments? Rebutting Moravcsik's position therefore necessitates a return to the coal face of the sources. Each of these questions is deliberately posed in the past tense, however: historians seek to represent what has already happened in European integration - including identifying cause and effect, and seeking patterns of influence and interaction by all means - rather than to create theories or hypotheses about the present or future.

Less comfortably for historians, engaging with Moravcsik forces self-reflection about methods and sources. If the assumption that individuals act 'rationally' is unsatisfactory, with what do we replace it? Historians surely have views about 'what people are like' and what motivates individuals and groups to act in particular ways, even if they are not as precisely expressed as those of social scientists. We have equally important views about the extent to which a 'true' representation of the past can be made, or the extent to which we trust archival sources or interview subjects in creating such a representation. Being honest about those assumptions - with ourselves as well as our readers and students - can only strengthen our historical practice through opening it to scrutiny. Only in this way can we assess Moravcsik's work on its own terms as well as from an historical perspective. Does he produce a theory with 'superior parsimony, coherence, empirical accuracy, and multicausal consistency', as he claims to seek to do in 'Taking Preferences Seriously'? Are his assumptions ('microfoundations') justifiable? Is 'parsimony' compatible with 'multicausal consistency'? Do the goals of parsimony, and coherence have an impact on 'empirical accuracy'? Has Moravcsik's empirical research been unduly skewed by the weight of his theoretical ideas? Historians are not immune from the danger of research questions (or availability of sources, or research grants) having an unjustifiable impact on the

39. A. MORAVCSIK, Is something rotten ..., op.cit., p.672 (he promises to return to this point but does not do so). 
structure of empirical research. Source selectivity is thus equally important for both fields, as Richard Evans' deconstruction of David Irving's sources has shown. ${ }^{40}$

Both Moravcsik's methodology and his empirical research, therefore, force historians to re-examine how we conceptualise and research European integration. The very discomfort and lack of fit between social science and history in this case compel both further empirical research, and greater precision and clarity in elaborating our goals and methods in studying history.

40. R. EVANS, Lying about Hitler: History, Holocaust and the David Irving Trial, Basic Books, New York, 2002. This example is not intended to suggest that Moravcsik is like Irving in his methods of handling sources, merely to demonstrate that historians (a title that Irving claims for himself) must look to their own practice of source use in addition to challenging those of social science. 


\title{
Book reviews - Comptes rendus - Buchbesprechungen
}

\author{
Roland DANNREUTHER (ed.) - European Union Foreign and Security Policy. \\ Towards a neighbourhood Strategy, Routledge, London and New York, 2004, 225 \\ p. - ISBN 0-415-32298-7 - 26,68 €.
}

Le débat actuel qui consiste à savoir si l'UE est un acteur international alimente de plus en plus la production éditoriale, signe indéniable de l'intérêt porté à ce questionnement, dont les conséquences sur le thème de l'identité européenne sont fortes. Il est abordé dans ce livre, édité par Roland Dannreuther, suivant une perspective particulière, qui consiste à juger si cette même UE défend une vision cohérente dans son environnement immédiat. C'est ainsi que sont passés en revue les différents pays et régions où l'Europe peut, ou pourrait développer une politique étrangère et de sécurité communes: Europe centrale et orientale bien entendu (Pál Dunay), Turquie (Gilles Dorronsoro), Europe sud-orientale (Ettore Greco), Russie, Ukraine, Moldavie et Belarus (Andrei Zagorski), Scandinavie (Hiski Haukkala), Caucase et Asie centrale (Neil MacFarlane), Afrique du Nord (Fred Tanner) et Moyen Orient (Roland Dannreuther), études empiriques auxquelles il faut ajouter des approches plus thématiques, celles d'Antonio Missiroli sur la notion de «voisinage», de William Wohlforth sur le lien transatlantique, et de John Gault sur la sécurité énergétique.

Onze cas au total sont étudiés, donnant un éclairage sur le rôle de l'UE dans certaines politiques de voisinage, avec une attention particulière au processus d'élargissement en Europe centrale et orientale, à l'engagement dans les Balkans, au conflit israélo-arabe, et à la politique à l'égard des pays de l'ex-URSS. Chaque contribution répond à cinq thèmes de recherche: le développement de politiques communautaires pertinentes (ou non) depuis la fin de la Guerre froide; l'impact de l'influence stratégique de l'UE; l'étendue de l'autonomie de cette dernière par rapport aux politiques des Etats membres; l'influence d'acteurs extérieurs dans les affaires européennes; le passage ou non de l'UE d'un statut de puissance civile à celui d'acteur stratégique. Le livre a paru dans les premiers mois de l'année 2004, avant donc l'adhésion officielle des dix à l'UE, et ne tient pas compte de certains événements forts ayant trait aux thèmes étudiés, tels que la révolution orange en Ukraine ou l'ouverture des négociations d'adhésion avec la Turquie.

Dans l'introduction, Roland Dannreuther, professeur à l'université d'Edimbourg, lui-même spécialiste des relations internationales, rappelle que la politique européenne de voisinage est une conséquence directe de l'après-Guerre froide: la nécessité de s'engager dans la stabilisation des pays de l'ancien Pacte de Varsovie s'est imposée peu après l'écroulement de l'hégémonie soviétique après 1989, et le résultat de ce fait fut et reste un défi stratégique et géopolitique consistant à remplir un vide inquiétant. Qui plus est, la logique interne de l'intégration européenne stipule que l'acquis communautaire ne saurait être limité à l'ouest mais devrait être étendu à l'est; or, l'avenir du projet d'intégration est lié au succès de l'engagement 